\title{
Entrepreneurship and innovativeness of small and medium-sized construction enterprises
}

\author{
Marcin W. Staniewski ${ }^{1} \cdot$ Robert Nowacki $^{1}$ • \\ Katarzyna Awruk ${ }^{2}$
}

Published online: 4 February 2016

C The Author(s) 2016. This article is published with open access at Springerlink.com

\begin{abstract}
The construction industry is a key industry in any economy. Due to its specific characteristics, the industry is of substantial importance to the development of other sectors. Competition is highly intense, and the industry itself is susceptible to changes in market circumstances that force the entities operating in it to continuously take actions to enhance their competitiveness by, among other things, introducing innovative solutions. The objective of the present study is to evaluate the level of innovativeness of enterprises in the small and medium-sized (SME) sector in the Polish construction industry and to identify the factors that influence this level of innovativeness, which relates to the location of the business and managers' awareness of the significance of innovation in shaping a firm's competitiveness. Qualitative research was conducted on a sample of 608 companies. The obtained results demonstrate that construction companies from the SME sector in Poland are characterized by a level of innovativeness that is similar to that found in other enterprises, which is a consequence of the relatively high awareness of the significance of innovation to obtaining a competitive position among the managers of these companies. An analysis of the innovative activities of these companies by location shows, in turn, that entities operating in regions that are less economically developed and less attractive in terms of investment are more innovative.
\end{abstract}

Marcin W. Staniewski

staniewski@vizja.pl

Robert Nowacki

nowacki@vizja.pl

Katarzyna Awruk

kawruk@op.pl

1 Faculty of Management and Finance, University of Finance and Management in Warsaw, 55 Pawia Str., 01-030 Warsaw, Poland

2 Faculty of Psychology, University of Finance and Management in Warsaw, 55 Pawia Str., 01-030 Warsaw, Poland 
Keywords Entrepreneurship - Competitive position - Regional development · Innovativeness $\cdot$ Management $\cdot$ Poland

\section{Introduction}

In recent years, a notable development of entrepreneurship has been observed in many countries. A similar trend has also been noticeable in Poland. Poland is the sixth largest economy in the European Union by number of enterprises (1.52 million companies) (Łapiński et al. 2013), whereas in terms of the number of newly established SMEs, Poland had the second most in 2010 - right behind France (Lapiński et al. 2013) which is particularly important when we consider the role played by this sector. In a general sense, the SME sector is the main motors behind a country growth, in job creation, and for innovation (Romero-Martinez et al. 2010). It is a milestone on the road toward economic progress, and makes a huge contribution towards the quality and future of a sector, economy or even a country's welfare (Mendez-Picazo et al. 2012; Ribeiro Soriano and Huarng 2013).

The development and commercialization of innovation play major roles in this respect (Radas and Božić 2009). According to Porter (1985), innovation increases the competitiveness of countries, particular sectors of the economy, or enterprises. It contributes to maintaining profitability, gaining a competitive advantage, and the long-run functioning of a company (Khazanchi et al. 2007). It also leads to improvement in quality in addition to enriching the range of products on offer, and it positively influences productivity, turnover, profitability, employment (Guinet and Pilat 1999), market position stabilization, degree of market share, operational effectiveness, reputation, and the ability to reduce costs (Abernathy and Clark 1985; Cooke and Mayes 1996). It may thus be stated that innovativeness is the main factor influencing the effectiveness of an enterprise (Talke et al. 2011) that operates under conditions of increasingly intense competition (Marinova 2004). In the SME sector in a highly industrialized economy (Leitner 2011), innovation has become a necessity if an enterprise is to survive and maintain a competitive advantage (Bos-Brouwers 2009; Van de Vrande et al. 2009). The key to obtaining this advantage is strategic orientation toward innovation, which is a certain manner of collecting pieces of advice and direction that lead to innovation (Gatignon and Xuereb 1997; Zhou et al. 2005). Innovation is one of the most important competitive strategies for both small and large enterprises (Kaufmann and Tödtling 2002). Hence, from the perspective of the entire economy, stimulation of innovation in the SME sector is a very important task (Keizer et al. 2002).

Innovations are of great significance in any sector of business activity. One such sector is the construction industry. Innovation plays a key role in leveraging the competitiveness of firms within the construction industry, particularly architectural and engineering design firms (Panuwatwanich and Stewart 2012). From the point of view of the whole national economy, this industry is characterized by a high level of dynamics; it constitutes approximately $10 \%$ of all entities, employs approximately $6 \%$ of all workers and contributes to approximately $7 \%$ of the gross domestic product (Lapiński et al. 2013). The construction industry is the largest contributor to the national economies of almost all developed nations and many more (Langford and 
Dimitrijevic 2002). Nevertheless, the construction industry is conservative by nature, and firms are reluctant to adopt new technologies (Shapira and Rosenfeld 2011). For this reason, innovation in the construction industry has been relatively slow (Yang et al. 1997), and the industry does not have a strong reputation for adopting innovative products (Esmaeili and Hallowell 2012).

The aim of this paper is to diagnose the innovativeness of small and medium-sized enterprises in the Polish construction industry and evaluate these enterprises against the other sectors of the economy (the general population).

The article presents a review of the relevant international literature concerned with innovation in the SME sector, which will be used as basis for putting forward research hypotheses. The research methodology used in studies carried out on the SME sector in the Polish construction industry and the results of empirical research (quantitative) will also be presented. Subsequently, the authors will generate a discussion based on the interpretation of the results, and finally, the main conclusions and recommendations for managers as well as policy makers will be presented.

\section{Background}

Innovation is a key driver of progress and development as well as a source of inventions in all areas of society, technology, and administration (Farazmand 2004: 8). Innovation is the one business activity that has been most closely related to economic growth (Guzman-Cuevas et al. 2009). From the business perspective, innovation is considered to be a strategic instrument that serves to build and enhance business capabilities (Farazmand 2004: 5) and it can be defined as the implementation of something new, original, significant, or valuable (Luecke and Katz 2003) or a significant change that occurs through an array of substantial improvements (to a product, process, or service) in comparison with previous accomplishments (Harper and Becker 2004). Innovation is concerned with novelty in terms of product, service, process, program, or device (Damanpour 1991), ideas, approaches, methods, processes, structures, behaviors, attitudes, and cultures as well as technology, capabilities in the management and administration of communities, and in the management of various types of organizations (Farazmand 2004: 8).

An issue that many researchers find interesting concerns the disparate approaches to innovation by SMEs and large companies and the degree of their effectiveness. Some researchers claim that innovation may be of even greater importance for the SME sector than for large companies (Fritz 1989).

Some studies show that innovation is more common among large (Harmancioglu et al. 2010) rather than small enterprises, but others show differently (Harmancioglu et al. 2010; Knight and Cavusgil 2004; Pelham 1999). However, it is inevitable to conclude that smaller companies have much more limited availability of resources, such as the financial or human capital, in comparison with larger companies (Forbes and Milliken 1999). Difficulty accumulating sufficient financial resources results in a lack of funds for innovation (Romero-Martinez et al. 2010), the refusal to take on the (often very high) risk of innovative projects, and foregoing the purchase of (frequently very costly) technology. Human capital play a significant role in the process of producing innovation (Galunic and Rodan 1998) and offers top managers the skills 
necessary to take advantage of new opportunities (Wiklund and Shepherd 2003). Moreover effects of human capital on performance may be different, or at least stronger, among SMEs than among larger firms (Ribeiro Soriano and Castrogiovanni 2012). The above-mentioned limitations also restrict companies' accessibility to market information, for instance, they can prevent them from conducting professional scientific research or purchasing industrial data (Burke and Jarrat 2004), or they can decrease their opportunities to develop new products (Kaufmann and Tödtling 2002).

Because of limited resources, SMEs are not able to do everything on their own and thus need cooperation (Hanna and Walsh 2002; Rogers 2004). Unfortunately, SMEs are usually less predisposed toward seeking and employing codified knowledge (especially scientific knowledge), which forces them to depend on personal means of dissemination of knowledge and the ability to learn through action and influence/cooperation. Furthermore, it is more difficult for them to use formal agreements for that purpose; thus, they must build on trust and informal relations.

Hence, it appears that innovativeness is of particular importance for small entrepreneurial companies with limited resources (Rhee et al. 2010; Van de Vrande et al. 2009). One of the advantages of the SME sector over large companies is the role that the owner/manager serves in promoting innovativeness (Bos-Brouwers 2009). The impact of the manager/owner in this regard will be stronger in small companies because there is less bureaucracy in these enterprises, their organizational structure is flat, they are less varied (Forbes and Milliken 1999), they have a flexible organizational culture, they have fewer formal systems and procedures and less planning activity (Busenitz and Barney 1997), and they are managed by a small group of dominating managers (Knight and Cavusgil 2004). However, the dominating role of a manager, entrepreneur, or owner of a company may also bring about adverse effects because of poor management skills in terms of planning, or they may concentrate on a shorter rather than a longerterm strategic perspective to obtain sustainable growth (Bos-Brouwers 2009). These issues can result from a lack of formal education or appropriate qualifications (Smallbone et al. 2000).

Small and medium-sized enterprises face a greater challenge in undertaking actions connected with seeking and adopting innovation than larger companies (Lubatkin et al. 2006; Mom et al. 2007).

However, as stated by Van Dijk et al. (1997), most researchers in the field of innovation in the SME sector come to the conclusion that there is no dramatic difference between small and large companies as far as innovativeness is concerned (there is no discrepancy between the quality and significance of the innovations they create).

Based on our analysis of the international literature provided above, the authors of the present paper have formulated the following hypothesis:

H1: the scale of implementation of innovative solutions in the SME sector in the Polish construction industry is similar to the scale of implementation characterizing the whole population of companies One of the most important factor shaping the innovative activity of companies is the strong leadership and advanced level of qualified of a highly educated manager or founder (Hoffman et al. 1998; Le Blanc et al. 1997) because top managers play a key role in identifying the objectives of innovative companies as well as in the process of implementation of an innovation 
(Camelo-Ordaz et al. 2008). The appropriate leadership style for an SME depends to a great extent on characteristics of its operating environment, its sector and geographical region. The leadership style that shows the best results is that transactional leadership style. Following this style SME achieve not only an extra effort by collaborators, who apply themselves to their tasks and duties with more determination, but they also show a considerable degree of satisfaction with the firm's performance and leadership (Franco and Matos 2015).

The majority of managers or founders are aware of the possibilities of using innovative solutions and conscious of the fact that each management area can be subject to innovation; however, they are not always capable of appropriately implementing it (Nowacki and Staniewski 2012).

Unfortunately, most of the managers in organizations equate innovation merely with developing products and continuous improvements however, a company's sustainable competitive advantage is no longer based on products and services because those are too easy to imitate. A competitive advantage arises exclusively out of the capability to completely rethink a business and follow a new path in running it, which can make an organization really stand out in the market.

The right qualifications of a manager ensure not only the proper management of human resources but also the efficient management of risk and change. These are the significant management areas that innovative enterprises commonly address.

If an organization wishes to be innovative, it is sometimes referred to as "doomed" to take risks (Horibe 2003: 26). It is not possible to be innovative while maintaining stability in an organization (i.e., avoiding change and risk). Stability and permanence are signs of a lack of innovation. Paradoxically, risk management in an innovative organization does not mean minimizing but increasing the level of risk. If an organization does not tolerate risk, it minimizes the level of creativity and innovativeness of its employees. Thus, an appropriate attitude of managers is required; it must be acceptable that employees will take risk and there might be costs incurred due to possible errors and mistakes (Kohli and Jaworski 1990). If such an attitude is adopted, employees will be more eager to seek and implement new solutions in response to the needs expressed by the market (He and Wong 2004).

Another contemporary concept of management used by innovative companies is management of change. This concept refers to facilitating the fast implementation of any changes/innovations through the identification of internal stakeholders, such as pioneers of change, change agents, and opportunists (malcontents), and exerting influence on them.

Taking into account the often extremely limited access to resources in an SME, it should be noted that the SME sector's weakness is often poor managerial competences (Forbes and Milliken 1999; Pissarides 1999) with respect to the effective management of the changing external and internal business environment (Ebben and Johnson 2005). In addition, some studies show (Salaman and Storey 2002) that managers often have trouble conceptualizing the nature of innovative organizations in practice.

As far as the Polish SME sector is concerned, both highly qualified experts and highly educated management staff are rare. Companies striving for the minimization of the costs of operation cannot afford such employees. An SME is often managed by one person who is the owner/entrepreneur (who frequently lacks management education) and is supported by the person's closest family members. It would be hard to expect 
such a manager to be conscious of the importance of innovation in the management of a business. Thus, the arguments provided above allow us to put forward the following hypothesis:

H2: managers in the SME sector in the Polish construction industry are characterized by a lower level of awareness of the significance of innovation in management for the sake of shaping a competitive position in comparison with the whole population of enterprises Keizer et al. (2002) grouped the external factors influencing innovation in the SME sector into three categories:

- cooperation with other companies,

- cooperation with knowledge centers,

- using external assistance (e.g., support and development programs for the SME offered by government agencies, including financial aid).

The main determinant that strongly influences the above external factors is the region in which a given company operates. A company's region represents a very significant background for supporting the process of innovation, chiefly due to the possibilities of cooperation with other entities in the market. The possibility of engaging in cooperation with other companies is considered by entrepreneurs to be a very important method to increase innovativeness (Chang 2003; Groen et al. 2008; Hanna and Walsh 2002; Massa and Testa 2008; Pittaway et al. 2004; Salman and Saives 2005; Santos-Rodrigues et al. 2011). A specific region can open up possibilities for direct face-to-face interactions, the exchange of hidden knowledge, and cooperation through common innovative projects. An additional advantage arising out of a close neighborhood of companies is the spatially limited mobility of labor and graduates - which are two very important mechanisms for the transfer of knowledge to companies (Kaufmann and Tödtling 2002). If the number of involved parties is higher, team members are more varied, which may exert a positive influence over creativity and the exchange of information and thus lead to better results in terms of innovation (Dahlin et al. 2005). It is worth emphasizing the significance of this variety. A lack of cooperation between suppliers of knowledge from outside the business sector severely limits external influence, which facilitates and stimulates the creation of innovations (Kaufmann and Tödtling 2002). Such a cooperation is based on the commitment of the partners. Commitment creates trust among them provided that the cooperation continues to develop satisfactorily (del Mar Benavides-Espinosa and Ribeiro-Soriano 2014). According to some researchers (Lawson et al. 2009; Rindfleisch and Moorman 2001), innovations in companies can be implemented specifically through cooperation with other organizations. Thus, the more companies that operate in a given region, the greater the chances for cooperation are (creation of consortia, clusters, etc.), which may consequently lead to an increase in innovativeness of the involved parties. Top managerial ties are significant in this regard; due to social interactions between business partners or the representatives of a government administration and local authorities, top managers are able to benefit from cooperation within a network (Shu et al. 2012). Additionally, due to the processes of creation of organizational knowledge, their companies may internalize those benefits and integrate them with their internal knowledge, which leads to the emergence of innovative products and/or processes (Shu et al. 2012). 
The intensity of support for the process of innovation in a region depends on the given institutional arrangement (e.g., universities and other research organizations, vocational education institutions, technology centers and transfer agencies) and the structure of the regional economy (the dominating industry, the accessibility of service firms and appropriate suppliers, organizations offering financial support for innovation, etc.) (Kaufmann and Tödtling 2002).

The external factors identified by Keizer et al. (2002), which influence innovation in the SME sector and its resulting possibilities, are thus a derivative of the attractiveness of the region where the companies operate. From the perspective of the process of innovation, the region is particularly important for SMEs (Cooke et al. 2000) because such enterprises are usually strongly integrated; thus, the factors determining their innovativeness are dependent on the nature of the region (Kaufmann and Tödtling 2002; Radas and Božić 2009). The above analysis of the literature has led to the formulation of another hypothesis:

\section{H3: there is a territorial difference in the scale of innovation implemented in the SME sector in the construction industry that is contingent upon the level of socioeconomic development of the regions in Poland}

\section{Methodology}

The main goal of this study was to determine the importance of innovativeness and the level of innovation implementation by Polish entrepreneurs representing the construction industry.

The quantitative research was carried out in 2013 and 2014 in the whole of Poland extending across all voivodeships, which are classified into four categories on the basis of the attractiveness of investment in each region (which results from socioeconomic development) according to the Gdansk Institute for Market Economics (Nowicki et al. 2011). The classification groups are as follows:

- group A - the most attractive voivodeships for investments (a value on the synthetic index of investment attractiveness over 0.5) - Silesian, Masovian, Lower Silesian;

- group B - voivodeships with a modestly positive value on the investment index between 0 and 0.5 - Lesser Poland, Greater Poland, West Pomeranian, Pomeranian;

- group C - voivodeships with a value on the investment attractiveness index between minus 0.3 and 0 - Łódź, Kuyavian-Pomeranian, Lubusz and Opole;

- group D - the least attractive voivodeships for investment, with attractiveness index values below minus 0.3 - Subcarpathian, Świętokrzyskie, Warmian-Masurian, Lublin, Podlaskie.

In general, the data were gathered from 608 entrepreneurs. The study group consisted of 169 (27.8\%) entrepreneurs from the construction industry, and the control group consisted of 439 (72.2\%) respondents from other industries (production and services). The study group was dominated by enterprises founded between 1991 and 2000 (40.8\%), employing between 50 and 249 employees $(52.7 \%)$ and belonging to group A (29.6 \%) (Masovian - 14.8 \%, Lower Silesian - $9.5 \%$, Silesian - $5.3 \%$ ) with 
an average position in the market (50.3\%) and an economic situation assessed by the respondents as "good" (47.9\%). Furthermore, in the study group, the monthly turnover of enterprises was higher than 2 million PLN (27.8\%), and the main source of capital was solely Polish (77.5\%).

In turn, the control group was represented by enterprises established between 1991 and 2000 (44.6\%), employing between 5 and 9 employees (40.01\%) and belonging to group A (30.1\%) (Masovian - $12.5 \%$, Silesian - $10.3 \%$, Lower Silesian - $7.3 \%$ ) with an average position in the market $(67 \%)$ and an economic situation assessed by the respondents as "good" $(49.7 \%)$. Detailed data about the study group and the control group are presented in Table 1.

The survey was conducted through direct, face-to-face interviews with entrepreneurs/owners and/or managers in charge of the studied entities. The interviews were conducted using a questionnaire prepared by the authors of this paper, which contained categorized questions. The questions included fifty substantive questions concerning the issue of innovation and implementation of innovative solutions in various areas of a company's operations (e.g., What is the importance of innovation (innovation solutions) in your firm?) and eleven questions describing the studied population of the enterprises (e.g., type of sector, voivodeship).

Statistical analyses were performed using SPSS for Windows 22.0 and descriptive statistics (frequencies), Student's t-test and the Kruskal-Wallis test were calculated, with $P<0.05$ accepted as the level of statistical significance.

\section{Main findings and discussion}

The first stage of the analysis was the verification of the hypothesis regarding the scale of implementation of innovation among enterprises in the Polish construction industry (H1). To achieve this goal, we tested how entrepreneurs in the construction industry evaluate their level of innovativeness against the competition, and whether the scale of implementation of innovation in the company is significantly higher than the corresponding scale for the group of entrepreneurs operating in other sectors. The obtained results demonstrate that most of the entrepreneurs in the construction industry see their level of innovativeness as similar to that of their competition (54.4\%). Only $30.8 \%$ of the entrepreneurs in the construction industry that have been examined consider themselves to be more innovative $-27.2 \%$ declare that they are rather more innovative, and $3.6 \%$ claim they are definitely more innovative (Fig. 1).

As far as evaluations of the level of innovativeness and the scale of implementation of innovation is concerned, the differences between entrepreneurs in the construction industry and entrepreneurs representing the other sectors are statistically insignificant $(P>.05)$ (Tables 2 and 3). Thus, Hypothesis 1 has been confirmed, and it may be assumed that the scale of implementation of innovative solutions in the SME sector in the Polish construction industry is similar to that characterizing the whole population of companies.

The next step in the analysis was to verify the hypothesis regarding the degree of awareness of entrepreneurs in the construction industry concerning the significance of innovation in management for shaping a competitive position (H2). Initially, it had been assumed that the degree of awareness would be smaller in the group of entrepreneurs in 
Table 1 Detailed data about the study sample and the control group

\begin{tabular}{|c|c|c|c|c|c|}
\hline & & \multicolumn{2}{|c|}{ Construction industry } & \multicolumn{2}{|c|}{ Other industries } \\
\hline & & $\mathrm{N}$ & $\%$ & $\mathrm{~N}$ & $\%$ \\
\hline \multirow[t]{4}{*}{ Year of establishment } & before 1971 & 54 & 32.0 & 44 & 10.0 \\
\hline & between 1971 and 1990 & 21 & 12.4 & 75 & 17.1 \\
\hline & between 1991 and 2000 & 69 & 40.8 & 196 & 44.6 \\
\hline & after 2000 & 25 & 14.8 & 124 & 28.2 \\
\hline \multirow[t]{3}{*}{ Number of employees } & between 5 and 9 & 44 & 26.0 & 176 & 40.1 \\
\hline & between 10 and 49 & 36 & 21.3 & 108 & 24.6 \\
\hline & between 50 and 249 & 89 & 52.7 & 155 & 35.3 \\
\hline \multirow[t]{4}{*}{ Operating range } & local & 37 & 21.9 & 179 & 40.8 \\
\hline & regional & 33 & 19.5 & 81 & 18.5 \\
\hline & national & 42 & 24.9 & 101 & 23.0 \\
\hline & international & 57 & 33.7 & 78 & 17.8 \\
\hline \multirow[t]{3}{*}{ Number of operated markets } & only one market & 112 & 66.3 & 361 & 82.2 \\
\hline & between 2 and 5 markets & 22 & 13.0 & 45 & 10.3 \\
\hline & more than 5 markets & 35 & 20.7 & 33 & 7.5 \\
\hline \multirow[t]{3}{*}{ Position in market } & weak & 8 & 4.7 & 35 & 8.0 \\
\hline & average & 85 & 50.3 & 294 & 67.0 \\
\hline & strong & 76 & 45.0 & 110 & 25.0 \\
\hline \multirow[t]{5}{*}{ Economic situation } & very well & 32 & 18.9 & 29 & 6.6 \\
\hline & good & 81 & 47.9 & 218 & 49.7 \\
\hline & acceptable & 49 & 29.0 & 180 & 41.0 \\
\hline & bad/difficult & 4 & 2.4 & 9 & 2.1 \\
\hline & very bad/very difficult & 3 & 1.8 & 3 & 0.7 \\
\hline \multirow[t]{6}{*}{ Monthly turnover } & up to 50000 PLN & 8 & 4.7 & 93 & 21.2 \\
\hline & 50 001-100 000 PLN & 21 & 12.4 & 69 & 15.7 \\
\hline & 100 001-500 000 PLN & 26 & 15.4 & 88 & 20.0 \\
\hline & 500 001-1 million PLN & 19 & 11.2 & 39 & 8.9 \\
\hline & 1-2 million PLN & 19 & 11.2 & 21 & 4.8 \\
\hline & over 2 million PLN & 47 & 27.8 & 45 & 10.3 \\
\hline \multirow[t]{2}{*}{ Source of capital } & solely Polish & 131 & 77.5 & 380 & 86.6 \\
\hline & foreign-mixed & 38 & 22.5 & 59 & 13.4 \\
\hline \multirow[t]{10}{*}{ Voivodeship } & Lubusz & 2 & 1.2 & 33 & 7.5 \\
\hline & Lesser Poland & 34 & 20.1 & 1 & .2 \\
\hline & Masovian & 23 & 13.6 & 57 & 13 \\
\hline & Opole & 22 & 13 & 18 & 4.1 \\
\hline & Subcarpathian & 28 & 16.6 & 15 & 3.4 \\
\hline & Silesian & 7 & 4.1 & 47 & 10.8 \\
\hline & Świętokrzyskie & 26 & 15.4 & - & - \\
\hline & Warmian-Masurian & 27 & 16 & - & - \\
\hline & Lower Silesia & - & - & 48 & 10.9 \\
\hline & Kuyavian-Pomeranian & - & - & 28 & 6.4 \\
\hline
\end{tabular}


Table 1 (continued)

\begin{tabular}{|c|c|c|c|c|c|}
\hline & & \multicolumn{2}{|c|}{ Construction industry } & \multicolumn{2}{|c|}{ Other industries } \\
\hline & & $\mathrm{N}$ & $\%$ & $\mathrm{~N}$ & $\%$ \\
\hline & Lublin & - & - & 28 & 6.4 \\
\hline & Lódź & - & - & 40 & 9.1 \\
\hline & Podlaskie & - & - & 27 & 6.2 \\
\hline & Pomeranian & - & - & 41 & 9.3 \\
\hline & Greater Poland & - & - & 37 & 8.4 \\
\hline & West Pomeranian & - & - & 19 & 4.3 \\
\hline \multirow[t]{4}{*}{ Group } & A & 50 & 29.6 & 132 & 30.1 \\
\hline & $\mathrm{B}$ & 35 & 20.7 & 97 & 22.1 \\
\hline & $\mathrm{C}$ & 41 & 24.3 & 102 & 23.2 \\
\hline & $\mathrm{D}$ & 43 & 25.4 & 108 & 24.6 \\
\hline
\end{tabular}

the construction industry. To verify the above-mentioned hypothesis, we first tested how entrepreneurs in the construction industry evaluate the significance of innovation for the development of a company. As Fig. 2 shows, the majority of the entrepreneurs in the construction industry consider the implementation of innovation to be important $(50.3 \%)$ or even very important $(15.4 \%)$.

Moreover, the entrepreneurs in the construction industry evaluate the significance of innovation and the influence of the implementation of innovation on improvements in competitiveness similarly to the entrepreneurs representing the remaining sectors (Tables 4 and 5). Therefore, Hypothesis 2 is not confirmed, and it may be assumed that entrepreneurs in the construction industry are characterized by a similar degree of awareness with regard to the significance of innovation in management for shaping a competitive position to the degree of awareness among the representatives of the whole population of enterprises.
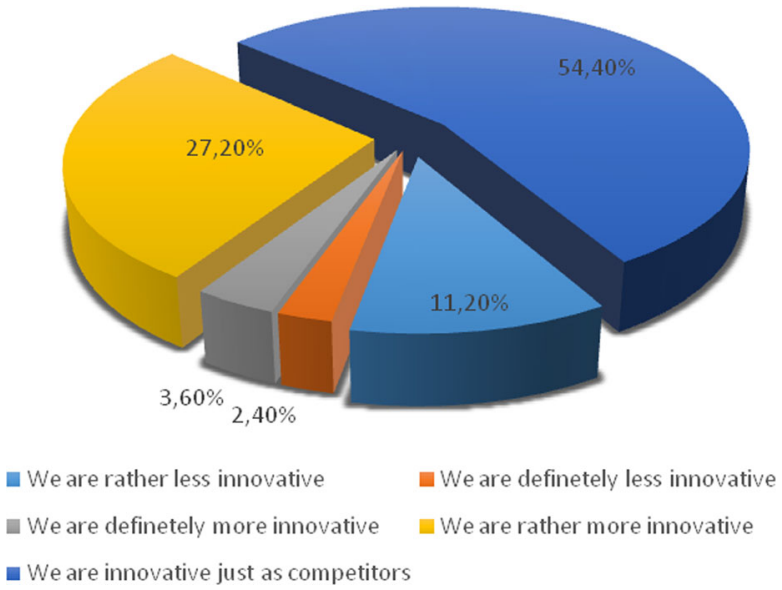

Fig. 1 Evaluation of the level of innovation compared with competitors in the opinion of Polish entrepreneurs from the construction industry 
Table 2 Differences in evaluation of the level of innovation compared with competitors between entrepreneurs from the construction industry and entrepreneurs from other industries

\begin{tabular}{|c|c|c|c|c|c|c|}
\hline & \multicolumn{2}{|c|}{ Construction industry } & \multicolumn{2}{|c|}{ Others } & \multirow[t]{2}{*}{$\mathrm{t}$} & \multirow[t]{2}{*}{$\mathrm{P}$} \\
\hline & M & SD & M & $\mathrm{SD}$ & & \\
\hline Level of innovation & 2.81 & .773 & 2.94 & .867 & -1.65 & .100 \\
\hline
\end{tabular}

The third step was verification of the hypothesis concerning territorial differentiation of the scale of implementation of innovative solutions by entrepreneurs in the construction industry (H3). In the last 2 years, the most innovative solutions were implemented by entrepreneurs in the construction industry from group D $(88.40 \%)$, and the least innovative solutions were implemented by entrepreneurs in the construction industry from group B (68.60\%). Furthermore, the majority of the innovative solutions in the upcoming two years will be implemented by entrepreneurs in the construction industry from group C (70.70\%), and the least will implemented by entrepreneurs in the construction industry from group B (40\%).

In addition, the Kruskal-Wallis test reveals statistically significant differences among entrepreneurs in the construction industry from groups A, B, C, and D in terms of the implementation of innovative solutions in particular areas of activity. As demonstrated in Table 6, entrepreneurs in the construction industry from group D implement the most innovative solutions on average in comparison with entrepreneurs in the construction industry from groups $\mathrm{A}, \mathrm{B}$, and $\mathrm{C}$ in the following areas: Management of production processes/technological processes, Work time organization, Product management, Distribution management, Pricing policy management, Market communication policy management, Marketing management, Human resources management, Finance management, Supplies management, and Counterparty management. In view of the above findings, Hypothesis 3 concerning territorial differentiation in the implementation of innovative solutions by entrepreneurs in the construction industry is confirmed, and it seems that entrepreneurs in the construction industry from group D are ahead in this respect.

\section{Conclusions and recommendations}

Studies have shown that the level of innovativeness of the SME sector in the Polish construction industry is satisfactory, i.e., comparable to the whole population of

Table 3 Differences in the level of innovation implementation between entrepreneurs from the construction industry and entrepreneurs from other industries

\begin{tabular}{|c|c|c|c|c|c|c|}
\hline & \multicolumn{2}{|c|}{ Construction industry } & \multicolumn{2}{|c|}{ Others } & \multirow[t]{2}{*}{$\mathrm{t}$} & \multirow[t]{2}{*}{$\mathrm{P}$} \\
\hline & M & SD & M & SD & & \\
\hline Innovation implementation & 0.21 & .411 & .24 & .430 & -.80 & .425 \\
\hline
\end{tabular}




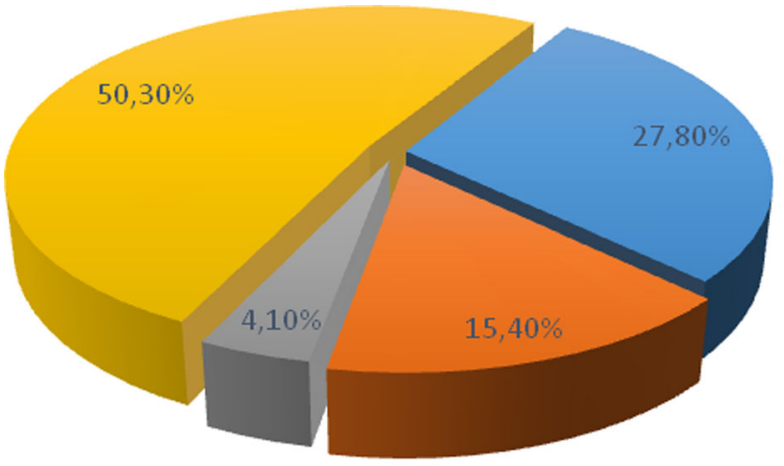

It is a little important $\mathbf{I t}$ is very important

It is not important $\quad$ It is important

Fig. 2 Indicator of the importance of innovation implementation for enterprise development in the opinion of Polish entrepreneurs from the construction industry $(N=169)$

enterprises operating in Poland. This state of affairs also finds confirmation in a high degree of awareness of the significance of innovativeness among managers/ entrepreneurs in the construction industry regarding the development of a competitive market position. Observations concerning the general population of enterprises in Poland are similar.

Additionally, it might be expected that the level of innovation in these enterprises will increase in the near future because they intend to implement further innovations in various areas of activity.

The perceivable territorial differentiation in innovative companies in the construction industry should be considered in the context of the uneven socioeconomic development of the regions in Poland. Large differences between regions between the most highly developed and the least developed result from their innovative potential, among other things. Spending on research and development as well as employment in this sector, the number of research-development units and research-development employees, the number and potential of innovation and entrepreneurship centers, and the coefficient of innovation measured by the number of patents per 100 residents are also decisive factors (Nowacki 2009). Studies show, however, that the innovative potential of a region itself is not always a determinant of the innovation in the companies that operate in it. In fact, the level of involvement in innovative activity is greater in enterprises situated in voivodeships that are considered to be the least attractive in terms of investment and therefore those where the innovative potential is

Table 4 Differences in the evaluation of the importance of innovation between entrepreneurs from the construction industry and entrepreneurs from other industries

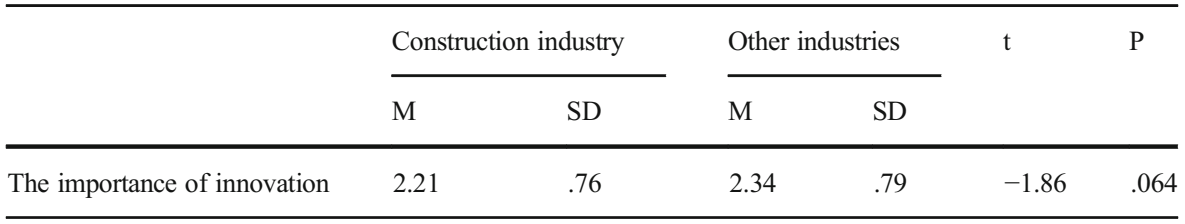


Table 5 Differences in the evaluation of the impact of innovation implementation on improvement in competitiveness in the market between the study sample and the control group

\begin{tabular}{|c|c|c|c|c|c|c|}
\hline & \multicolumn{2}{|c|}{ Construction industry } & \multicolumn{2}{|c|}{ Other industries } & \multirow[t]{2}{*}{$\mathrm{t}$} & \multirow[t]{2}{*}{$\mathrm{P}$} \\
\hline & M & SD & M & $\mathrm{SD}$ & & \\
\hline Innovation implementation impact & .34 & .48 & .34 & .47 & .09 & .930 \\
\hline
\end{tabular}

relatively low. These factors result from their poor starting point. Because they operate under more difficult conditions and have restricted access to modern solutions, these entities are forced to seek new paths to shape their competitiveness by taking chances to present themselves as more innovative to increase their chances of survival. An additional stimulus is access to financial resources granted by the EU, which are intended to support innovative activity or eliminate the disparities in regional development. Aid from the European Union makes the financial barriers to the development of innovation in companies independent from the region in which they operate (Juchniewicz and Grzybowska 2010), and sometimes it is easier to obtain funds for innovation in voivodeships with the smallest potential. The use of solutions that are characteristic of networked organizations, e.g., clusters, contributes to that access (Dabrowska 2014), as such solutions may increase the chances for the development of the SME sector in the construction industry.

A more formidable barrier is the problems related to the creation of innovative solutions. Dulaimi et al. (2002) list a lack of coordination between academia and

Table 6 Differences in innovation implementation among enterprises from the construction industry in groups A, B, C, and D

\begin{tabular}{|c|c|c|c|c|c|c|}
\hline & $\begin{array}{l}\text { Group A } \\
N=50 \\
\text { Mean rank }\end{array}$ & $\begin{array}{l}\text { Group B } \\
N=35 \\
\text { Mean rank }\end{array}$ & $\begin{array}{l}\text { Group C } \\
N=41 \\
\text { Mean rank }\end{array}$ & $\begin{array}{l}\text { Group D } \\
N=43 \\
\text { Mean rank }\end{array}$ & $\begin{array}{l}\text { Chi- } \\
\text { Square }\end{array}$ & $\mathrm{P}$ \\
\hline $\begin{array}{l}\text { Management of production/ } \\
\text { technological processes }\end{array}$ & 82.13 & 66.30 & 94.28 & 94.71 & 14.00 & .003 \\
\hline Management of work organization & 78 & 75.80 & 83.88 & 101.70 & 9.77 & .021 \\
\hline Product management & 85.28 & 79.80 & 73.24 & 100.12 & 11.86 & .008 \\
\hline Distribution management & 80.45 & 71.10 & 86.09 & 100.57 & 12.64 & .005 \\
\hline Management of price politics & 82.13 & 75.90 & 79.94 & 100.57 & 10.23 & .017 \\
\hline Quality management & 73.59 & 83.30 & 93.43 & 91.62 & 6.86 & .076 \\
\hline $\begin{array}{l}\text { Management of market } \\
\text { communication politics }\end{array}$ & 82.55 & 77.70 & 80.74 & 97.85 & 9.79 & .020 \\
\hline Marketing management & 74.92 & 87.40 & 81.49 & 98.12 & 9.01 & .029 \\
\hline Human recourse management & 81.22 & 73.60 & 84.49 & 99.16 & 10.34 & .016 \\
\hline Knowledge management & 81.57 & 83.90 & 81.79 & 92.94 & 3.50 & .321 \\
\hline Financial management & 83.04 & 75.80 & 75.39 & 103.93 & 14.57 & .002 \\
\hline Supply management & 77.86 & 83.20 & 74.24 & 105.02 & 18.34 & .000 \\
\hline Contractor management & 72.75 & 77.30 & 89.18 & 101.52 & 14.87 & .002 \\
\hline
\end{tabular}


industry as a major hindrance to innovation in construction. In general, the research centers operating in Poland note a lack of demand for their accomplishments (such as innovative technologies, products, or services) on the part of companies operating in the market. This lack of demand is particularly relevant for regions perceived as the most highly developed, e.g., Mazowsze (Mackiewicz 2007).

\section{Limitations and further research}

The study presented above is subject to several limitations. First, an analysis of the results for particular types of construction activities was not conducted (as they were treated as uniform activities); the results were analyzed with reference to the whole population of enterprises, and thus their character was not captured. It would also be advisable to select a larger sample of companies from each type of construction activity (similar in terms of size). It would be interesting to carry out analyses for each type of construction activity in relation/comparison to the whole SME sector in the construction industry (and not to the whole population of companies). In addition, it is recommended that a different method using objective innovation measures should be applied in such a study, where such measures do not rely upon the declarations and impressions of the managers/owners of those companies.

Open Access This article is distributed under the terms of the Creative Commons Attribution 4.0 International License (http://creativecommons.org/licenses/by/4.0/), which permits unrestricted use, distribution, and reproduction in any medium, provided you give appropriate credit to the original author(s) and the source, provide a link to the Creative Commons license, and indicate if changes were made.

\section{References}

Abernathy, W. J., \& Clark, K. B. (1985). Innovation: mapping the winds of creative destruction. Research Policy, 14, 3-22.

Bos-Brouwers, H. E. J. (2009). Corporate sustainability and innovation in SMEs: evidence of themes and activities in practice. Business Strategy and the Environment, 19, 417-435.

Burke, I., \& Jarrat, D. (2004). The influence of information and advice on competitive strategy definition in small- and medium-sized enterprises. Qualitative Market Research, 7(2), 126-138.

Busenitz, L., \& Barney, J. (1997). Differences between entrepreneurs and managers in large organizations: biases and heuristics in strategic decision making. Journal of Business Venturing, 12, 9-30.

Camelo-Ordaz, C., Fernandez-Alles, M. L., \& Valle-Cabrera, R. (2008). Top management team's vision and human resources management practices in innovative Spanish companies. The International Journal of Human Resource Management, 19(4), 620-638.

Chang, Y. C. (2003). Benefits of Co-operation on innovative performance: evidence from integrated circuits and biotechnology firms in the UK and Taiwan. R\&D Management, 33, 425-437.

Cooke, I., \& Mayes, P. (1996). Introduction to innovation and technology transfer. Norwood, MA: Artech.

Cooke, P., Boekholt, P., \& Tödtling, F. (2000). The governance of innovation in Europe: regional perspectives on global competitiveness. London: Pinter.

Dąbrowska, A. (2014). Innowacyjność klastrów [cluster innovation]. In B. Bojewska (Ed.), Innowacyjność organizacji sieciowych $w$ gospodarce opartej na wiedzy [innovativeness of networked organizations in a knowledge-based economy]. SGH.: Warszawa.

Dahlin, K. B., Weingart, L. R., \& Hinds, P. J. (2005). Team diversity and information use. Academy of Management Journal, 48(6), 1107-1123.

Damanpour, F. (1991). Organizational innovation: a meta-analysis of effects of determinations and moderators. Academy of Management Journal, 34(3), 555-590. 
del Mar Benavides-Espinosa, M., \& Ribeiro-Soriano, D. (2014). Cooperative learning in creating and managing joint ventures. Journal of Business Research, 67, 648-655.

Dulaimi, M. F., Ling, F. Y. Y., Ofori, G., \& De Silva, N. (2002). Enhancing integration and innovation in construction. Building Research and Information, 30(4), 237-247.

Ebben, J. J., \& Johnson, A. C. (2005). Efficiency, flexibility, or both? Evidence linking strategy to performance in small firms. Strategic Management Journal, 26(13), 1249-1259.

Esmaeili, B., \& Hallowell, M. R. (2012). Diffusion of safety innovations in the construction industry. Journal of Construction Engineering and Management, August, 955-963.

Farazmand, A. (2004). Innovation in strategic human resource management: building capacity in the age of globalization. Public Organization Review, 4(1), 3-24.

Forbes, D., \& Milliken, F. (1999). Cognition and corporate governance: understanding boards of directors as strategic decision-making groups. Academy of Management Review, 12, 117-132.

Franco, M., \& Matos, G. M. (2015). Leadership styles in SMEs: a mixed-method approach. International Entrepreneurship and Management Journal, 11(2), 425-451.

Fritz, W. (1989). Determinants of product innovation activities. European Journal of Marketing, 23(10), 3243.

Galunic, C., \& Rodan, S. (1998). Resource recombinations in the firm: knowledge structures and the potential for Schumpeterian innovation. Strategic Management Journal, 19(12), 1193-1201.

Gatignon, H., \& Xuereb, J.-M. (1997). Strategic orientation of the firm and new product performance. Journal of Marketing Research, 34(1), 77-90.

Groen, A. J., Wakkee, I. A. M., \& DeWeerd-Nederhof, P. C. (2008). Managing tensions in a high-tech start-up: an innovation journey in social system perspective. International Small Business Journal, 26, 57-81.

Guinet, J., \& Pilat, D. (1999). Promoting innovation: does it matter? OECD Observer, 217(128), 63-65.

Guzman-Cuevas, J., Caceres-Carrasco, R., \& Ribeiro Soriano, D. (2009). Functional dependence and productive of SMEs. Small Business Economics, 32, 317-330.

Hanna, V., \& Walsh, K. (2002). Small firm networks: a successful approach to innovation? $R \& D$ Management, 32, 201-207.

Harmancioglu, N., Grinstein, A., \& Goldman, A. (2010). Innovation and performance outcomes of market information collection efforts: the role of top management team involvement. International Journal of Research in Marketing, 27, 33-43.

Harper, S. M., \& Becker, S. W. (2004). On the leading edge of innovation: a comparative study of innovation practices. Southern Business Review, 29, 1-15.

He, Z.-L., \& Wong, P.-K. (2004). Exploration vs. exploitation: an empirical test of the ambidexterity hypothesis. Organization Science, 15(4), 481-494.

Hoffman, K., Parejo, M., Bessant, J., \& Perren, L. (1998). Small firms, R\&D technology and innovation in the UK: a literature review. Technovation, 18(1), 39-55.

Horibe, F. (2003). No risk, no innovation: does innovation happen because of HR's systems or in spite of them? Canadian HR Reporter, 16(21), 26.

Juchniewicz, M., \& Grzybowska, B. (2010). Innowacyjność mikroprzedsiębiorstw w polsce [innovativeness of microenterprises in Poland]. Warszawa: PARP.

Kaufmann, A., \& Tödtling, F. (2002). How effective is innovation support for SMEs? An analysis of the region of Upper Austria. Technovation, 22, 147-159.

Keizer, J., Dijstra, L., \& Halman, J. I. M. (2002). Explaining innovative efforts of SMEs. An exploratory survey among SMEs in the mechanical and electrical engineering sector in The Netherlands. Technovation, 22, 1-13.

Khazanchi, S., Lewis, M. W., \& Boyer, K. K. (2007). Innovation-supportive culture: the impact of organizational values on process innovation. Journal of Operations Management, 25(4), 871-884.

Knight, G. A., \& Cavusgil, S. T. (2004). Innovation, organizational capabilities, and the born global firm. Journal of International Business Studies, 35(2), 1-18.

Kohli, A. K., \& Jaworski, B. J. (1990). Market orientation: the construct, research propositions, and managerial implications. Journal of Marketing, 54(2), 1-18.

Langford, D., \& Dimitrijevic, B. (2002). Construction creativity casebook. Canada: Thomas Telford Publishing, ASCE Press.

Łapiński, J., Nieć, M., Rzeźnik, G., \& Zakrzewski, R. (2013). Małe i średnie przedsiębiorstwa w polsce [small and medium-sized enterprises in Poland]. In A. Tarnawa, P. Zadura-Lichota (Eds.). Raport o stanie sektora malych i średnich przedsiębiorstw $w$ polsce $w$ latach 2011-2012 [report on the condition of small and medium-sized enterprises in Poland between 2011 and 2012]. Warszawa: Polska Agencja Rozwoju Przedsiębiorczości. Retrieved from http:/www.parp.gov.pl/files/74/81/626/18670.pdf 
Lawson, B., Petersen, K. J., Cousins, P. D., \& Handfield, R. B. (2009). Knowledge sharing in interorganizational product development teams: the effect of formal and informal socialization mechanisms. Journal of Product Innovation Management, 26(2), 156-172.

Le Blanc, L. J., Nash, R., Gallagher, D., Gonda, K., \& Kakizaki, F. (1997). A comparison of US and Japanese technology management and innovation. International Journal of Technology Management, 13(5-6), $601-614$.

Leitner, K.-H. (2011). The effect of intellectual capital on product innovativeness in SMEs. International Journal of Technology Management, 53(1), 1-18.

Lubatkin, M. H., Simsek, Z., Ling, Y., \& Veiga, J. F. (2006). Ambidexterity and performance in small- to medium sized firms: the pivotal role of top management team behavioral integration. Journal of Management, 32(5), 646-672.

Luecke, R., \& Katz, R. (2003). Managing creativity and innovation. MA: Harvard Business School Press.

Mackiewicz, M. (2007). Formy Powiązań instytucji Naukowo-Badawczych z Przedsiębiorstwami - Wyniki Badań Ankietowych i Studiów Przypadków [Forms of Connections Between Science-Research Institutions and Enterprises - the Results of Questionnaire Surveys and Case Studies]. In M. A. Weresa (Ed.), Transfer Wiedzy z Nauki do Biznesu. Doświadczenia Regionu Mazowsze [Transfer of Knowledge from Science to Business. Experience of the Mazowsze Region]. Warszawa: SGH.

Marinova, D. (2004). Actualizing innovation effort: the impact of market knowledge diffusion in a dynamic system of competition. Journal of Marketing, 68(3), 1-20.

Massa, S., \& Testa, S. (2008). Innovation and SMEs: misaligned perspectives and goals among entrepreneurs, academics, and policy makers. Technovation, 28(7), 393-407.

Mendez-Picazo, M.-T., Galindo-Martin, M.-A., \& Ribeiro-Soriano, D. (2012). Governance, entrepreneurship and economic growth. Entrepreneurship \& Regional Development, 24(9-10), 865-877.

Mom, T. J. M., Van Den Bosch, F. A. J., \& Volberda, H. W. (2007). Investigating managers' exploration and exploitation activities: the influence of top-down, bottom-up, and horizontal knowledge inflows. Journal of Management Studies, 44(6), 910-931.

Nowacki, R. (2009). Potencjał innowacyjny regionu jako czynnik rozwoju regionalnego [innovative potential of a region as a factor of regional development]. Prace Naukowe Uniwersytetu Ekonomicznego we Wroctawiu, 46, 62-71.

Nowacki, R., \& Staniewski, M. (2012). Innovation in the management of SMEs in the service sector in Poland. Amfiteatru Economic, XIV(Special 6), 755-773.

Nowicki, M., Hildebrandt, A., Susmarski, P., \& Tarkowski, M. (2011). Atrakcyjność inwestycyjna województw i podregionów polski. In 2011 [investment attractiveness of voivodships and subregions in Poland, 2011]. Gdańsk: IBnGR.

Panuwatwanich, K., \& Stewart, R. A. (2012). Evaluating innovation diffusion readiness among architectural and engineering design firms: empirical evidence from Australia. Automation in Construction, 27, 50-59.

Pelham, A. (1999). Influence of environment, strategy, and market orientation on performance in small manufacturing firms. Journal of Business Research, 45, 33-46.

Pissarides, F. (1999). Is lack of funds the main obstacle to growth? EBRDs experience within small-and medium-sized business in central and eastern Europe. Journal of Business Venturing, 14, 519-539.

Pittaway, L., Robertson, M., Munir, K., Denyer, D., \& Neely, A. (2004). Networking and innovation: a systematic review of the evidence. International Journal of Management Reviews, 5/6, 137-68.

Porter, M. E. (1985). Competitive advantage: creating and sustaining superior performance. New York: Free Press.

Radas, S., \& Božić, L. (2009). The antecedents of SME innovativeness in an emerging transition economy. Technovation, 29, 438-450.

Rhee, J., Park, T., \& Lee, D. H. (2010). Drivers of innovativeness and performance for innovative SMEs in South Korea: mediation of learning orientation. Technovation, 30, 65-75.

Ribeiro Soriano, D., \& Castrogiovanni, G. J. (2012). The impact of education, experience and inner circle advisors on SME performance: insight from a study of public development centers. Small Business Economics, 38, 333-349.

Ribeiro Soriano, D., \& Huarng, K.-H. (2013). Innovation and entrepreneurship in knowledge industries. Journal of Business Research, 66, 1964-1969.

Rindfleisch, A., \& Moorman, C. (2001). The acquisition and utilization of information in new product alliances: a strength-of-ties perspective. Journal of Marketing, 65(2), 1-18.

Rogers, M. (2004). Networks, firm size and innovation. Small Business Economics, 22, 141-153.

Romero-Martinez, A. M., Ortiz-de-Urbina-Criado, M., \& Ribeiro Soriano, D. (2010). Evaluating European Union support for innovation in Spanish small and medium enterprises. The Service Industries Journal, $30(5), 671-683$. 
Salaman, G., \& Storey, J. (2002). Managers' theories about the process of innovation. Journal of Management Studies, 39(2), 147-165.

Salman, N., \& Saives, A. L. (2005). Indirect networks: an intangible resource for biotechnology innovation. R\&D Management, 35, 203-215.

Santos-Rodrigues, H., Dorrego, P. F., \& Fernandez-Jardon, C. M. (2011). The main intellectual capital components that are relevant to the product, process and management firm innovativeness. International Journal of Transitions and Innovation Systems, 1(3), 271-301.

Shapira, A., \& Rosenfeld, Y. (2011). Achieving construction innovation through academia-industry cooperation - keys to success (pp. 223-231). October: Journal of Professional Issues in Engineering Education \& Practice.

Shu, C., Page, A. L., Gao, S., \& Jiang, X. (2012). Managerial ties and firm innovation: is knowledge creation a missing link? Journal of Product Innovation Management, 29(1), 125-143.

Smallbone, D., North, D., \& Vickers, I. (2000). The role and characteristics of SMEs. In A. Isaksen, B. T. Asheim, C. Nauwelaers, D. North, \& F. Tödtling (Eds.), SME Policy and the Regional Dimension of Innovation. Oslo: Final report of the TSER-research project SMEPOL.

Talke, K., Salomo, S., \& Kock, A. (2011). Top management team diversity and strategic innovation orientation: the relationship and consequences for innovativeness and performance. Journal of Product Innovation Management, 28, 819-832.

Van de Vrande, V., De Jong, J. P. J., Vanhaverbeke, W., \& De Rochemont, M. (2009). Open innovative in SMEs: trends, motives and management challenges. Technovation, 9, 423-437.

Van Dijk, B., Den Hertog, R., Menkveld, B., \& Thurik, R. (1997). Some new evidence on the determinants of large and small firm innovation. Small Business Economics, 9, 335-343.

Wiklund, J., \& Shepherd, D. (2003). Knowledge-based resources. Entrepreneurial orientation, and the performance of small and medium-sized business. Strategic Management Journal, 24, 1307-1314.

Yang, L. R., O’Connor, J. T., \& Chen, J. H. (1997). Assessment of automation and integration technology's impacts on project stakeholder success. Automation in Construction, 16(6), 725-733.

Zhou, K. Z., Yim, C. K. B., \& Tse, D. K. (2005). The effects of strategic orientations on technology and market-based breakthrough innovations. Journal of Marketing, 69(2), 42-60. 